\title{
Livestock and Climate Justice: Challenging Mainstream Policy Narratives
}

\section{Fernando Garcia-Dory, Ella Houzer and lan Scoones}

\begin{abstract}
In discussions around food systems and the climate, livestock is often painted as the villain. While some livestock production in some places contributes significantly to climate change, this is not universally the case. This article focuses on pastoral production systems - extensive, often mobile systems using marginal rangelands across around half of the world's surface, involving many millions of people. By examining the assumptions behind standard calculations of greenhouse gas emissions, a systematic bias against pastoralism is revealed. Many policy and campaign stances fail to discriminate between different material conditions of production, lumping all livestock systems together. Injustices arise through the framing of debates and policy knowledge; through procedures that exclude certain people and perspectives; and through the distributional consequences of policies. In all cases, extensive livestock keepers lose out. In reflecting on the implications for European pastoralism, an alternative approach is explored where pastoralists' knowledge, practices and organisations take centre-stage.
\end{abstract}

Keywords climate justice, pastoralism, extensive livestock, life cycle assessment, methane, Europe.

\section{Introduction \\ Livestock have become the villains of the climate change debate. They produce significant quantities of greenhouse gases, notably methane, and the climate footprint of meat and milk production is potentially huge. The argument follows that livestock production should be reduced, if not eliminated, and an alternative diet, based on plant products or 'cultured' meats, should be adopted. But which livestock, where? Whose diets? What science justifies this, based on which assumptions and what data?}


This article argues that the generalised narrative, if universally applied to all livestock production systems, is misplaced and unjust. Yet versions of it, with various nuances, are now widely promoted by international organisations, governments, businesses, think tanks and campaign groups. The general narrative is supported by well-known celebrities from David Attenborough to Greta Thunberg, and is showered across the media, while profitable alternatives to animal-source foods are backed by everyone from Bill Gates to the World Economic Forum. ${ }^{\text {? }}$

There is no doubt that some livestock production is immensely damaging - either through changes in habitat, including deforestation to create ranches or farmed feed, or through intensively farmed systems with high greenhouse gas emissions across the system from production to consumption. But this does not apply to all livestock systems, particularly extensive pastoralism that supplies high-density protein to often vulnerable populations and generates income from areas that otherwise would not be used for agricultural production. It is therefore vitally important to differentiate between production systems and not just focus on the potentially negative qualities of the products, whether meat, milk, cheese or wool.

Current climate debates focusing on livestock production and changing diets urgently need more sophistication. They are generating exclusions and creating injustices, as particular sources of knowledge are favoured over others in the assessment of climate impacts. This creates biases in procedures that guide policy choices. These in turn have important implications as the world contemplates how to reduce emissions levels so that temperature rises are restricted to $1.5^{\circ} \mathrm{C}$, while supporting livelihoods and development.

This article focuses on pastoralists who make use of extensive, highly variable rangelands, often through flexible mobility (Krätli 2019; Scoones 2021; Manzano et al. 2021). These are harsh environments, where alternative production options and land uses would require high levels of external inputs and would not be sustainable. Rangelands make up more than half the planet's land surface (ILRI et al. 2021) and are a site of important biodiversity, ecosystem services, and the home for many millions of pastoralists. Pastoralists produce from a diversity of animal species - camels, yaks, cattle, goats and sheep, reindeer and llamas. They live in areas ranging from the Arctic Circle to the savannahs and semi-deserts of Africa, and in the mountains and steppes of Asia and Latin America.

Towards the end of this article, we focus on the situation in Europe, where livestock keepers make use of the hills and mountains of the Mediterranean region and parts of northern Europe, the diverse meadow pastures of the Alps, Pyrenees and other mountain ranges, and the extensive rangelands of the 
tundra in the far north. In their production of meat and milk - and a huge range of other animal products - pastoralists provide an important source of nutrition, alongside luxury goods for high-end markets. Such production allows pastoralists to gain an income and livelihood, and so they can continue to live in and make use of such environments, providing protection and guardianship of these landscapes.

The article is organised as follows. First, we identify some of the key narratives and the underlying data (Section 2). In Section 3, we look at where these data come from, including the oft-repeated iconic statistics that frame the debate. Then in Section 4, we examine the assumptions behind the science and look at the inherent biases. We ask how this affects pastoralists, and what patterns of exclusion and forms of injustice result (Section 5). Finally, in Section 6, we explore the implications for the case of European pastoralists before concluding.

\section{Climate and livestock: dominant narratives}

Policy narratives as storylines about the world define both problems and solutions, making use of particular types of knowledge along the way. Importantly, policy narratives have power, associated with different networks and advocacy groupings (Keeley and Scoones 2003). When backed by formal, accredited science, they gain authority and credibility and so help to frame debates. That they also reflect realities - in some places, at some times, for some people - makes them appealing to those with prior commitments and particular biases and incentives. When they fit a wider storyline about the need to do something urgently about climate change, it is understandable that they have appeal.

Narratives about climate change and livestock have emerged in this way over the past 15 years. A number of influential reports, starting with Livestock's Long Shadow emanating from the Food and Agriculture Organization of the United Nations (FAO) (Steinfeld et al. 2006), set the terms. Based on an analysis of secondary data making use of life cycle assessments of livestock production, the reports highlighted the potential damage of continued greenhouse gas emissions from livestock systems. Livestock produce methane through anaerobic digestion. When combined with emissions from manure and other elements of the livestock production, processing and marketing system, this can add up to considerable amounts.

Estimates vary, but one much repeated figure suggests that livestock (directly and indirectly through the whole production system including transport, feed, infrastructure and so on) contribute 14.5 per cent of total anthropogenic greenhouse gas emissions (Gerber et al. 2013). This is clearly a large figure in need of reduction, but simplistic comparisons used in climate campaigns by Greenpeace and others ${ }^{2}$ argue that this is 
equivalent to the whole of the transport sector, forgetting that calculations on transport only include direct emissions and not the full sector (Mottet and Steinfeld 2018). Meanwhile, the media pick up the argument, often without digging into the details. On the back of a major publication in the journal Science (Poore and Nemecek 2018), the UK broadsheet The Guardian proclaimed, "Avoiding meat and milk is the "single biggest way" to reduce your impact on Earth' (Carrington 2018).

Quite appropriately, land-use change and agricultural production have increasingly become a focus for attention in debates of climate change policy, now that shifts to low-carbon alternatives in energy, housing and transport are well under way, driven by major price shifts, technological advances and increasingly strict government regulation. Land use and agriculture seem more intractable, given the trade-offs and vested interests involved. However, in an attempt to assess the evidence and push the issue up the agenda, the Intergovernmental Panel on Climate Change (IPCC) produced a landmark report in 2019 on this theme arguing for a suite of technical mitigation options in the livestock sector. The report listed an array of solutions from manure and slurry management, to animal breeding, to methane-reducing vaccination (IPCC 2019), despite widespread scepticism of the practicality of many of the solutions offered (Goopy 2019).

A focus on changing production and land use is combined with attention to consumption and diets. Reducing meat and milk consumption is seen by many concerned with climate change as important for encouraging a shift to diets centred on plant-based or cultured meat alternatives. The EAT Lancet report offered a 'planetary diet', with adjustments for different world regions, that would not cross both environmental sustainability and human health boundaries (Willett et al. 2019). ${ }^{3}$ While not arguing to exclude meat and milk, as advocates for a purely vegan diet do, the EAT Lancet report called for massive reductions in consumption of animal-source foods worldwide. Among the 'consumption elite' of many Western countries, this undoubtedly will be beneficial both for personal health and the planet. Yet questions have been raised about affordability and the impact of alternative diets in many parts of the world, and particularly the consequences for those reliant on animal-source foods for nutrition (Beal et al. 2017; Ryckman et al. 2021).

As arguments against livestock production and animal-source foods build (with varying degrees of qualification and nuance), and are adopted by everyone from UN organisations and campaign organisations to politicians and well-respected celebrities, a new political economy of production and food emerges. Powerful commercial interests intervene to offer alternatives, such as cultured meat. These alternatives are heralded as the answer to the climate challenge and supported by companies such as Impossible Meats, a network of venture 
capitalist funders and philanthropist backers. The 'big meat' corporate sector, including major producers such as Tyson from the US and JBS from Brazil, have enormous lobbying power and counter arguments for any dietary switch, arguing that they are protecting the 'rights' of consumers (Weis 2013). ${ }^{4}$

But where in this are the millions of pastoralists and other small-scale, low-input extensive livestock keepers who produce animal products from diverse rangelands, supplying often poor populations alongside growing urban consumers with high-quality products? The voice of pastoralists goes unheard while globalised narratives play out in a new political economy of climate change food production. This is creating exclusions and injustices, often hidden from view in the wider global debates about climate change and food policy that go on in global conferences of the parties for climate or biodiversity or the huge UN gatherings around food systems.

\section{Science and climate policy: creating injustices}

Policy narratives on climate depend highly on the authority and legitimacy of science. The IPCC is the pinnacle of the global process and involves an elaborate procedure for assessing accredited evidence from multiple sources. A series of panels is formed to look at everything from global climate modelling to socioeconomic impacts, and the panels are populated by scientists from the world over. But the process has limitations (Beck and Mahony 2018). There are multiple uncertainties, now increasingly acknowledged, yet there are also strong incentives to reach definitive conclusions and to set targets (Asayama et al. 2019). Although more varied today, certain types of science dominate the process, with the majority of contributors based in the global North. Such a process can work only with the formal data that are available, a requirement that narrows discussions to the centres of knowledge production, frequently derived from a narrow range of countries and settings.

For good reason, the IPCC has gained legitimacy and authority on climate change science and, when a report emerges, policymakers from global to national level sit up and listen. Reports are long and complex with much detail. On livestock production globally and on the benefits of shifting to plant-based diets, a number of key sources are frequently relied upon. The two FAO reports noted earlier (Steinfeld et al. 2006; Gerber et al. 2013) are hugely influential, as is the analysis by Poore and Nemecek (2018).

This latter study was picked up widely in the media, with a number of 'iconic statistics' emerging. For example, The Guardian presented graphics claiming that 'Beef results in up to $105 \mathrm{~kg}$ of greenhouse gases per $100 \mathrm{~g}$ of protein, while tofu produces less than $3.5 \mathrm{~kg}^{\prime}$; and that 'More than $80 \%$ of farmland is used for livestock but it produces just $18 \%$ of food calories and $37 \%$ of 
protein' (Carrington 2018). Looking in more detail at the Poore and Nemecek publication and the 76 pages of supplementary material published separately, the limitations of the analysis are clear (and indeed admitted by the authors). The study was based on a meta-analysis of livestock production life cycle analyses - where all the emissions are measured, from production and processing to transport and retail - across 38,700 farms and 1,600 processors. It is an impressive data set, but almost exclusively focused on intensive, industrialised production, often in contained units with no free grazing. Nearly all the data were from Europe and North America, with some from Latin America and coastal China. Systems deemed 'subsistence' production were excluded from the analysis. The results reinforced the dominant narrative about the need to address livestock-related emissions and reduce consumption of animal-source food, and were shared widely in the media (see, for example, Petter 2020). Unfortunately, a more nuanced picture was not available, and the dominant narrative became further entrenched.

The now widely shared anti-livestock stance has knock-on consequences, as campaigners in other areas pick up the narrative in support of their agendas. For example, those promoting 'land-sparing' or 'half-earth' positions on conservation may envisage the intensification of livestock production or its replacement by industrialised meat and milk alternatives, releasing land for 'rewilding', conservation and biodiversity protection (Wilson 2016; Folberth et al. 2020). Major global initiatives that call for a commitment by all governments to a target of 30 per cent of land for biodiversity conservation by 2030 often present reducing land-extensive livestock production as central to this. ${ }^{5}$ Those who see extensive livestock production as causing land degradation and desertification add to the clamour, despite many long-standing debates that show how such production systems, including pastoralism, may actually increase biodiversity and preserve landscapes when livestock and people are not constrained by other land uses that restrict movement, for example (Behnke and Mortimore 2016).

A poor understanding of diverse extensive livestock systems, including pastoralism, can result in patterns of enclosure for conservation and environmental protection, resulting in exclusions of people and animals from areas that have long co-evolved with livestock use. Different imaginaries ${ }^{6}$ of 'wilderness' and environmental integrity are imposed, often by urban-based environmentalists with limited knowledge and appreciation of the lived-in landscapes used by livestock keepers. Injustices result through processes of 'green grabbing' and exclusion, rooted in divergent perspectives and understandings of environmental processes. Too often, the justification given for such moves is to address climate change, with the iconic figures on the assumed climate impact of livestock inevitably trotted out. 


\section{Biases, gaps and assumptions: differentiating the dominant narrative}

As any of the scientists involved in the assessments that produce such figures would admit, there is much more to life cycle analyses than the figures promoted in media headlines. Digging into the data can reveal nuance and differentiate between cases. The problem is that certain biases in data, assumptions and the way systems are bounded persist, giving a misleading impression for the uninitiated.

A review of 164 life cycle analyses of food products showed that only 0.4 per cent were derived from Africa, while most were focused on industrial systems (Clark and Tilman 2017). In order to make calculations of total contributions to greenhouse gas emissions, inputs and outputs are traced along the product life cycle and calculated in terms of a carbon dioxide-equivalent measure. Emissions, if not directly measured, are estimated according to recommended emissions factors for a 'standard' animal, while equivalence between greenhouse gases is estimated in relation to conversion factors that evaluate the potential for global warming. Emissions of carbon dioxide equivalents are assessed in relation to units of product (meat, milk etc.) and so carbon footprints are assessed within a productivist lens of product efficiency, rather than a broader view of multi-functionality across diverse contributions from a livestock system (Houzer and Scoones 2021).

Many assessments take place in contained industrial units with imported feed and limited grazing, so the complexities of the carbon cycle and its spatial and temporal dynamics are often excluded, including patterns of carbon and nitrogen sequestration on open grassland. Meanwhile, the assessments assume that additional livestock result in additional impacts from an assumed neutral baseline; it is forgotten that - in extensive systems - alternative land uses may not be possible (as crops or trees will not grow) and removal of livestock may result in their replacement with other greenhouse-gas-producing animals, whether wild ruminants or termites (Manzano and White 2019).

All these seemingly technical approaches, published in endless papers in scientific journals, frame the results in particular ways, making assumptions that bias the results. In other words, the way the science is conducted, the sources of data used and the assumptions made do not usually account for the practices central to extensive livestock systems, such as those practised by mobile pastoralists on rangelands. Box 1 summarises the set of biases, gaps and assumptions around the data, the way systems are understood and bounded, and the understandings and definitions of alternatives and baselines.

Extrapolating across types of livestock production systems and drawing 'global' conclusions about shifting production 
systems or transforming diets is therefore highly problematic. When conducting life cycle assessments and generating recommendations for policy, the biases and assumptions in the approach need to be taken into account. When this is done, quite different conclusions can arise.

For example, in Sardinia, Italy, a series of studies show how semi-extensive systems have potential benefits over more

\section{Box 1 Ten limitations of dominant life cycle analyses}

\section{Data}

Biases in the data - The majority of life cycle assessments make use of data from high-income countries and industrial systems. 'Global' assessments are therefore highly partial.

Default emissions factors - Most studies use default emissions factors, which do not reflect pastoral conditions.

Greenhouse gas measures - The 'global warming potential' is very different for short- (methane) and long-term (carbon dioxide) greenhouse gases. Factors that create equivalence may result in biases.

\section{Systems}

Conceptualising 'efficiency' - Emissions per unit of output (milk or meat) may look very different to other measures. A wider systems-level assessment is required to capture multi-functional use and diverse impacts.

Livestock and the carbon cycle - Carbon sequestration can be significant with light grazing in extensive, mobile systems. Such systems may be in balance or seasonally negative, meaning that livestock may not be net contributors to emissions.

Spatial and temporal dynamics - Emissions may be positive or negative in one area or at one time in extensive systems. This requires much more focused mitigation measures compatible with pastoralists' practices.

Ecosystem services - Bounded farm-level assessments miss wider contributions of extensive livestock to biodiversity and environmental and landscape improvements.

\section{Baselines and alternatives}

Alternative land uses - Abandoning livestock in favour of 'rewilding' or 'land-sparing' initiatives may not have the expected benefits. Tree planting for example, may not be as beneficial as sustaining grasslands for carbon sequestration, especially in dryland and montane environments.

Niche replacement - If livestock are removed, the areas will be filled by other species, including wild ruminants and termites. Emission reductions may even be negative and certainly much lower than predicted.

Diet and consumer choice - Hypothetical diets may undermine nutrition of vulnerable human populations, particularly in the early years of life. 
intensive systems, given the high carbon costs of feed imports and the opportunities for carbon sequestration (Arca et al. 2021; Vagnoni et al. 2017). Similar results were found in Amdo Tibet in China when extensive and more intensive systems were compared (Zhuang et al. 2017). A detailed study of carbon balances in a mobile pastoral region of Senegal in West Africa showed that they could be in balance, and even be negative at certain times of year, if the whole system was taken into account (Assouma et al. 2019).

Through these studies, alongside many others, the possibilities for carbon (and nitrogen) sequestration by extensively grazed animals are shown, along with the wider ecosystem service and landscape conservation benefits of such patterns of production. While multiple short trips for marketing by artisanal producers may produce more emissions than bulk transport and supply in industrial systems, there are other opportunities for mitigation in extensive systems. These include light mobile grazing, resulting in increased sequestration in regenerating grasslands; the management of manure in ways that disperse deposition through movement rather than concentrating it near water sources and in slurry pits; and the addition of browse and tannin-rich feed to reduce methane production during rumination (Herrera 2020).

A wider 'systems' approach, encompassing the diversity of costs and benefits of extensive livestock production, is therefore required, with data collection attuned to local contexts, with mobility, spatial heterogeneity and temporal patterns of seasonality included in the calculations. Such assessments may allow a more rounded evaluation for policy. Livestock keepers must be included in such assessments, as it is their local knowledge of systems that can help in understanding system boundaries and functions, and the possibilities for transformation to reduce emissions.

Going beyond the narrow focus on formal, accredited science adopted by the IPCC, with the resulting biases and distortions, suggests the opportunity to set a wider, more encompassing frame. This would be centred on an understanding of complex, dynamic systems, which emerges from a more inclusive approach to knowledge production, and a pluralised approach that sees conventional life cycle assessments sit alongside more participatory appraisals involving livestock keepers. Solutions to climate challenges thus emerge across multiple pathways, informed by diverse sociotechnical imaginaries and knowledge sources.

Extensive systems, using often poor-quality forage, certainly may result in significant methane emissions, but these may be offset by sequestration in open rangelands, facilitated by mobile patterns of light grazing and supported by careful, skilled herding. As providers of a diversity of goods, such livestock systems may have 
a wide range of benefits, including for biodiversity and ecosystem services. When different types of knowledge are included, a more differentiated picture emerges, as pastoral and other extensive livestock systems may have substantial benefits both for people and the environment, offering the possibilities for carbon neutrality under the right conditions.

\section{Rethinking climate and livestock policy processes}

As we have shown, generalised narratives based on aggregated science, where biases, assumptions and gaps are hidden or ignored, can cause great damage. Such narratives can generate injustices and exclusions when they are captured by particular interests - from those advocating alternative industrial meat or milk products that they have invested in to those promoting other imagined 'wild' landscapes without people and animals and sometimes, bizarrely, alliances between the two positions. What emerges from these narratives are 'epistemic injustices' through the way that science is constructed and knowledges are incorporated - and 'procedural injustices' - through the way that such science defines the processes of assessment, the definition of metrics and the form of reporting in global policy processes, whether around climate, food or biodiversity. And these result in forms of 'distributive injustice', where certain people lose out - in this case, it is those who are already marginalised, without power and often living in marginal areas away from the centres of power and knowledge production (cf. Newell et al. 2020).

The processes by which such injustices arise are often insidious and incremental, and sometimes happen by default rather than design. The IPCC, for example, does not have a firm position on livestock production but makes use of available data, based on accredited science, and so therefore misses out on a nuanced and differentiated picture, as we have discussed. Those advocating for biodiversity protection may adopt a vision of conservation and preservation based on long histories of conservation practice, mostly in the West, where exclusion and so-called 'fortress conservation' have long dominated policy discourse and practice. Those advocating changes in diets may see the devastating impacts on health and nutrition in some populations from the consumption of excess animal products, particularly processed foods, and advocate a shift, while forgetting about issues of availability, affordability and the particular importance of high-density protein and certain animal-derived nutrients in certain people's diets (Moughan 2021).

In the processes of policymaking, the need to aggregate and simplify pervades. This emerges perhaps especially in 'global' policy arenas with the focus on targets, boundaries and protocols for simple reporting - whether through Nationally Determined Contributions to climate mitigation through the Conference of the Parties (COP) process or whether in relation to dietary changes according to specified boundaries (even regionally adjusted). 
The consequence is that those working in under-resourced government departments and in charge of a policy area, whether on food, environmental protection or climate, may inevitably take the global standard or recommended protocol without questioning it. However, this can undermine the livelihoods of often poor and marginalised people and create injustice, even without any wilful intent.

\section{Confronting injustices: the case of European pastoralism}

All these processes that generate injustices in the climatelivestock debate more widely apply in the European context. Already, major announcements have been made at the European level that urge a shift in diets and propose huge tree-planting campaigns. These inevitably will affect rangelands used by pastoralists. In the UK, proposals for planting trees and transforming the countryside have been announced as part of the post-Brexit settlement with farmers, combined with a review of food systems that pushes a particular view on dietary change, focusing on a 'protein transition' away from meat consumption. ${ }^{8}$

Pastoralists, who herd sheep, goats, cattle and reindeer, are important in every corner of Europe, and often are central to the revitalisation of remote areas that have suffered long-term patterns of depopulation (Farinella and Nori 2020; Kerven and Behnke 2011). Extensive livestock production provides employment for migrant workers from Eastern Europe and North Africa and so offers incomes to often highly marginalised people (Nori 2017). As a source of high-quality artisanal produce, the skills of cheese making, meat curing and traditional wool production are shared and maintained, boosting local economies (Aubron et al. 2014). There is also a growing interest in local gastronomy, with particular foods protected by European Union geographical indications and so enhancing local food cultures and heritage.

Yet, such conditions are under threat. A poor understanding of pastoral systems is evident in many European settings as urban populations become disconnected from the countryside. This rupture has created a discourse that presents livestock production as polluting, generating disease risks and contributing to the climate catastrophe. The bovine spongiform encephalopathy (BSE) epidemic (also known as 'mad cow disease') in the UK, worries about animal welfare, concerns about the importation of hormone-grown meat, pollution from intensive livestock units and wider shifts in lifestyle and culture mean that negative attitudes about livestock production prevail among many consumers. If probed, most would admit that this is a distaste for industrial production, particularly 'factory farming', but such imagery affects all livestock. This is perhaps particularly evident in northern Europe - including the Netherlands, Denmark and Germany - where there has been a major consolidation in the meat industry. The decline in demand for meat products, for instance in Spain, has led to a switch in market destinations. 
Because lambs are no longer required in such large numbers for Easter, producers have had to shift to supplying Middle Eastern markets for Eid some weeks later.

A simplistic, protectionist vision of conservation promoted by environmentalist groups often casts pastoralists as destroyers of wildilife and landscapes, while rewilding advocates celebrate the reintroduction of wolves, bears and other predators. This generates tensions between pastoralists and urban environmentalists, fostering distrust and further misunderstandings. This has been especially the case in the French Pyrenees, but also elsewhere in southern Europe (Nori and Berzi 2021). Across Europe, such divisions are in turn exploited by far-right, authoritarian populist political forces who offer a narrative of protecting 'the people' from interference by the state and the influence of urban, elite environmentalism. For example in Spain, the right-wing, nationalist Vox party has made in-roads into rural areas, enlisting pastoralists and setting up opposition between their interests and those of 'leftist' radical vegans, rewilding enthusiasts and conservationists from town (Vampa 2020). Real resentments by pastoralists and smallholder farmers after years of state neglect and exclusion from policy processes combine with concerns about declining markets and the effects of predator reintroductions. Such grievances feed divisions, with regressive political forces exploiting discontents generated by repeated injustice.

There are thus intersecting injustices affecting European pastoralists: epistemic injustices resulting from distorted discourses and poor understandings of pastoral contexts; procedural injustices emerging from the lack of access to decision-making power by pastoralists living in remote, rural settings; and distributive injustices that result from pastoralists being marginalised across national and Europe-wide policy priorities. In order to confront these overlapping forms of injustice, movements committed to supporting pastoralists and a lived-in, productive European countryside need to generate an alternative narrative, and in turn influence how science-policy processes around climate and biodiversity unfold.

This is already happening. For example, across Europe, there are growing numbers of young people applying to attend shepherds schools, suggesting renewed interest in pastoralism and rural lifestyles. As guardians of often remote, montane landscapes, pastoralists enhance such settings, providing wider values for tourism and recreation, as well as protecting watersheds and enhancing biodiversity (FAO 2021). A focus on community and territory affirms the cultural importance of pastoral production, even with new producers coming from urban areas to join long-term and now ageing rural populations.

Such initiatives are supported by a diversity of pastoralist organisations, which together offer a new narrative for European 
pastoralism. For example, the European Shepherds Network that connects pastoralists across the continent and which is linked to the World Alliance of Mobile Indigenous Peoples (WAMIP), argues forcefully that pastoralism is about care - for animals, environments, landscapes and the climate. Pastoralism, such movements argue, also welcomes migrants, supports unemployed youth, offers opportunities for women and can be the basis for educational experiences for young people. Pastoralists provide healthy food to society, encourage local markets and avoid the damage of free trade and industrial production. Through celebrating self-management, autonomy and independence, pastoralists help keep the countryside alive with both people and animals (see PASTRES 2021). However, mobilising such a perspective in the face of powerful players promoting commercial interests and alternative visions of nature is challenging, especially when divisive, populist constituencies act to divide pastoralists' alliance-building.

\section{Conclusion}

Confronting the climate challenge requires a more nuanced debate about science and policy, and the role of livestock in environmental change. Injustices can arise when generalised narratives, captured by particular interests, are promoted. Science is always partial and political, which is why attention needs to be given to the framing of challenges, defining 'the system' and the use of data, and always acknowledging biases and limitations. We must ask whose knowledge is included and whose is excluded, linking scientific assessments - including often highly technical life cycle assessments - to questions of justice. Exclusions that emerge from epistemic, procedural and distributive injustices can damage life chances, while not achieving the aims of environmental protection and climate mitigation.

In thinking about alternative science-policy processes, we must always focus on politics that produce knowledge for policy. In this case, it is imperative to emphasise the nature of the production system and the material conditions and relations under which meat, milk and other animal products are produced. This situates the debate about livestock and climate in context, highlighting the interests and commitments associated with different types of production. The forms of labour, sources of knowledge and the environmental imprints of extensive livestock pastoral systems are quite different to those of industrial systems produced through capitalist relations. Given that there are multiple types of livestock production systems, each with different climate impacts, we must accept that there are multiple types of animal-source foods, each with different implications for climate change. The same applies to the political economy of 'alternatives', whether this is 'plant-based' production of proteins or the promise of cultured meat or the visions of conservation through enclosure that some environmentalists advocate. The debate therefore 
must be about the processes of production (and their social and political relations), not the products (whether meat, milk or plants). A focus on the political economy of policymaking highlights whose interests are central, and what alliances - sometimes unusual ones - are formed in order to silence perspectives on environment and livelihoods from pastoralists and other extensive livestock keepers.

Developing a more differentiated debate around the relationships between climate, livestock production and diet requires incorporating diverse knowledges, plural perspectives and context-specific analysis in international assessments (Scoones 2009). Perspectives on 'cognitive justice' mean rethinking the role of citizens in knowledge production and policy (Visvanathan 2005; Leach et al. 2005); and, in this case, involving pastoralists very directly in the co-production of science and assessment processes (Jasanoff 2004). Relying just on remote, elite science inevitably results in biases, reinforcing narratives and wider sociotechnical imaginaries, influenced by an urban environmentalism that is removed from the daily experience of pastoral settings (Jasanoff and Kim 2015; Beck et al. 2021). Such processes, in turn, construct a future for people and the environment that may be neither compatible with pastoral livelihoods nor address the real challenges of climate and environmental change. Instead, deliberating on processes of knowledge construction and the pathways of change that emerge - involving pastoralists and other livestock keepers and their movements directly - provides an alternative way forward that avoids over-simplified, standardised and unjust narratives about livestock and climate change.

\section{Authors}

Fernando Garcia-Dory grew up between Madrid and his family farm in the northern Spanish mountains. Over several decades, he has been involved in the Spanish peasant movement Plataforma Rural, part of La Via Campesina, and was involved in the creation of the Spanish Shepherds Federation and the European Shepherds Network. Currently he is also European Regional Coordinator for WAMIP, the World Alliance of Mobile Indigenous Peoples.

Ella Houzer is a former postgraduate student at the University of Sussex, with an MSc in Climate Change, Development and Policy.

Ian Scoones is a Professor at the Institute of Development Studies, University of Sussex. He is Co-Director of the ESRC STEPS (Social, Technological and Environmental Pathways to Sustainability) Centre (www.steps-centre.org) and Principal Investigator of the PASTRES programme (Pastoralism, Uncertainty and Resilience: Global Lessons from the Margins, pastres.org), funded by a European Research Council Advanced Grant. 


\section{Notes}

* This article draws from the longer report Are Livestock Always Bad for the Planet? Rethinking the Protein Transition and Climate Change Debate (Houzer and Scoones 2021), produced by the PASTRES programme (Pastoralism, Uncertainty and Resilience: Global Lessons from the Margins, pastres.org) in alliance with a number of organisations. The PASTRES Programme is supported through a European Research Council Advanced Grant (Number: 740342). Many thanks to Ann Waters-Bayer for providing a thorough review and a comprehensive edit of the article.

1 See, for example, Dalton (2020), Bugga (2021), Temple (2021) and World Economic Forum (2021).

2 Greenpeace European Unit (2020). See also Harvey (2020) and, also from earlier, Lean (2006).

3 See also EAT-Lancet Commission on Food, Planet, Health.

4 See also Sharma (2018).

5 See Campaign for Nature 30x30.

6 Social imaginaries are defined by Charles Taylor as 'common understanding that makes possible common practices and a widely shared sense of legitimacy' (2003: 23).

7 For example, Channel 4 documentary Apocalypse Cow: How Meat Killed the Planet.

8 See UK Government (2021) and Case (2021) for the UK, while for the EU's biodiversity strategy, see Vaughan (2020).

\section{References}

Arca, P.; Vagnoni, E.; Duce, P. and Franca, A. (2021) 'How Does Soil Carbon Sequestration Affect Greenhouse Gas Emissions from a Sheep Farming System? Results of a Life Cycle Assessment Case Study', Italian Journal of Agronomy 16.3: 1789

Asayama, S.; Bellamy, R.; Geden, O.; Pearce, W. and Hulme, M. (2019) 'Why Setting a Climate Deadline is Dangerous', Nature Climate Change 9.8: 570-72

Assouma, M.H. et al. (2019) 'Pastoral Landscapes in the Sahel: A Carbon Balance with Unexpected Potential for Climate Change Mitigation', Perspective (English Edition) 52: 1-4

Aubron, C.; Peglion, M.; Nozières, M-O. and Boutonnet, J-P. (2014) 'Quality Schemes and Pastoralism in France: Synergies and Paradoxes', Journal of Alpine Research 102.2

Beal, T.; Massiot, E.; Arsenault, J.E.; Smith, M.R. and Hijmans, R.J. (2017) 'Global Trends in Dietary Micronutrient Supplies and Estimated Prevalence of Inadequate Intakes', PloS ONE 12.4: e0175554

Beck, S. and Mahony, M. (2018) 'The IPCC and the New Map of Science and Politics', Wiley Interdisciplinary Reviews (WIREs): Climate Change 9.6: e547

Beck, S.; Jasanoff, S.; Stirling, A. and Polzin, C. (2021) 'The Governance of Sociotechnical Transformations to Sustainability', Current Opinion in Environmental Sustainability 49: $143-52$ 
Behnke, R. and Mortimore, M. (eds) (2016) 'Introduction: The End of Desertification?', in R. Behnke and M. Mortimore (eds), The End of Desertification? Disputing Environmental Change in the Drylands, Berlin: Springer

Bugga, H. (2021) 'Greta Thunberg Talks Animals, the Environment, and More in Groundbreaking New Video', Mercy for Animals, 22 May (accessed 12 October 2021)

Carrington, D. (2018) 'Avoiding Meat and Dairy is "Single Biggest Way" to Reduce Your Impact on Earth', The Guardian, 31 May (accessed 12 October 2021)

Case, P. (2021) 'Meat Production Slammed in Leaked Food Strategy Paper', Farmers Weekly, 12 July (accessed 12 October 2021)

Clark, M. and Tilman, D. (2017) 'Comparative Analysis of Environmental Impacts of Agricultural Production Systems, Agricultural Input Efficiency, and Food Choice', Environmental Research Letters 12.6: 064016

Dalton, J. (2020) 'Go Vegetarian to Save Wildlife and the Planet, Sir David Attenborough Urges', The Independent, 26 August (accessed 12 October 2021)

FAO (2021) Pastoralism - Making Variability Work, FAO Animal Production and Health Paper 185, Rome: Food and Agriculture Organization of the United Nations

Farinella, D. and Nori, M. (2020) 'Lessons from the Mountains: Mobility and Migrations in Euro-Mediterranean Agro-Pastoralism', in J.F. Rye and K. O'Reilly (eds), International Labour Migration to Europe's Rural Regions, London: Routledge

Folberth, C. et al. (2020) 'The Global Cropland-Sparing Potential of High-Yield Farming', Nature Sustainability 3.4: 281-89

Gerber, P.J. et al. (2013) Tackling Climate Change Through Livestock: A Global Assessment of Emissions and Mitigation Opportunities, Rome: Food and Agriculture Organization of the United Nations

Goopy, J.P. (2019) 'Creating a Low Enteric Methane Emission Ruminant: What is the Evidence of Success to the Present and Prospects for Developing Economies?', Animal Production Science 59.10: 1769-76

Greenpeace European Unit (2020) 'Animal Farming in EU Worse for Climate than All Cars', Greenpeace, press release, 22 September (accessed 12 October 2021)

Harvey, F. (2020) 'EU's Farm Animals "Produce More Emissions than Cars and Vans Combined"', The Guardian, 22 September (accessed 12 October 2021)

Herrera, P.M. (ed.) (2020) Extensive Farming and Climate Change: An In-Depth Approach, Madrid: Fundación Entretantos

Houzer, E. and Scoones, I. (2021) Are Livestock Always Bad for the Planet? Rethinking the Protein Transition and Climate Change Debate, Brighton: PASTRES (accessed 12 October 2021)

ILRI, IUCN, WWF, FAO, UNEP and ILC (2021) Rangelands Atlas, Nairobi: International Livestock Research Institute, International Union for Conservation of Nature, World Wide Fund for Nature, 
Food and Agriculture Organization of the United Nations, United Nations Environment Programme and International Land Coalition

IPCC (2019) Climate Change and Land: An IPCC Special Report on Climate Change, Desertification, Land Degradation, Sustainable Land Management, Food Security, and Greenhouse Gas Fluxes in Terrestrial Ecosystems, Geneva: International Panel on Climate Change

Jasanoff, S. (ed.) (2004) States of Knowledge: The Co-Production of Science and Social Order, London: Routledge

Jasanoff, S. and Kim, S-H. (eds) (2015) Dreamscapes of Modernity: Sociotechnical Imaginaries and the Fabrication of Power, Chicago IL: Chicago University Press

Keeley, J. and Scoones, I. (2003) Understanding Environmental Policy Processes: Cases from Africa, London: Earthscan Publications

Kerven, C. and Behnke, R. (2011) 'Policies and Practices of Pastoralism in Europe', Pastoralism 1: 28 (accessed 12 October 2021)

Krätli, S. (2019) Valuing Variability: New Perspectives on Climate Resilient Dryland Development, London: International Institute for Environment and Development

Leach, M.; Scoones, I. and Wynne, B. (eds) (2005) Science and Citizens: Globalization and the Challenge of Engagement, London and New York NY: Zed Books

Lean, G. (2006) 'Cow "Emissions" More Damaging to Planet than CO2 from Cars', The Independent, 10 December (accessed 12 October 2021)

Manzano, P. and White, S.R. (2019) 'Intensifying Pastoralism May Not Reduce Greenhouse Gas Emissions: Wildlife-Dominated Landscape Scenarios as a Baseline in Life-Cycle Analysis', Climate Research 77.2: 91-97

Manzano, P. et al. (2021) 'Toward a Holistic Understanding of Pastoralism', One Earth 4.5: 651-65

Mottet, A. and Steinfeld, H. (2018) 'Cars or Livestock: Which Contribute More to Climate Change?', Thomson Reuters Foundation News, 18 September (accessed 12 October 2021)

Moughan, P.J. (2021) 'Population Protein Intakes and Food Sustainability Indices: The Metrics Matter', Global Food Security 29: 100548

Newell, P.; Srivastava, S.; Naess, L.O.; Torres Contreras, G.A. and Price, R. (2020) Towards Transformative Climate Justice: Key Challenges and Future Directions for Research, IDS Working Paper 540, Brighton: Institute of Development Studies (accessed 12 October 2021)

Nori, M. (2017) 'Migrant Shepherds: Opportunities and Challenges for Mediterranean Pastoralism', Journal of Alpine Research 105: 4 Nori, M. and Berzi, D. (2021) The Uncertainties of Co-Existing with Predators: Experiences from Southern Europe, Pastoralism, Uncertainty, Resilience (PASTRES) blog, 21 May (accessed 12 October 2021) 
PASTRES (2021) Challenging Negative Views of Pastoralism in Europe: Q\&A with Fernando García-Dory, PASTRES blog, 13 September (accessed 12 October 2021)

Petter, O. (2020) 'Veganism is "Single Biggest Way" to Reduce Our Environmental Impact, Study Finds', The Independent, 24 September (accessed 12 October 2021)

Poore, J. and Nemecek, T. (2018) 'Reducing Food's Environmental Impacts through Producers and Consumers', Science 360.6392: 987-92

Ryckman, T.; Beal, T.; Nordhagen, S.; Chimanya, K. and Matji, J. (2021) 'Affordability of Nutritious Foods for Complementary Feeding in Eastern and Southern Africa', Nutrition Reviews 79(Suppl. 1): 35-51

Scoones, I. (2021) 'Pastoralists and Peasants: Perspectives on Agrarian Change', Journal of Peasant Studies 48.1: 1-47

Scoones, I. (2009) 'The Politics of Global Assessments: The Case of the International Assessment of Agricultural Knowledge, Science and Technology for Development (IAASTD)', Journal of Peasant Studies 36.3: 547-71

Sharma, S. (2018) 'Mighty Giants: Leaders of the Global Meat Complex', Institute for Agriculture and Trade Policy, 10 April (accessed 12 October 2021)

Steinfeld, H. et al. (2006) Livestock's Long Shadow: Environmental Issues and Options, Rome: Food and Agriculture Organization of the United Nations

Taylor, C. (2003) Modern Social Imaginaries, Durham NC: Duke University Press

Temple, J. (2021) 'Bill Gates: Rich Nations Should Shift Entirely to Synthetic Beef', Technology Review, 14 February (accessed 12 October 2021)

UK Government (2021) 'Tree Planting Rates to Treble by End of this Parliament', press release, 17 May (accessed 12 October 2021)

Vagnoni, E.; Franca, A.; Porqueddu, C. and Duce, P. (2017) 'Environmental Profile of Sardinian Sheep Milk Cheese Supply Chain: A Comparison between Two Contrasting Dairy Systems', Journal of Cleaner Production 165: 1078-89

Vampa, D. (2020) 'Competing Forms of Populism and Territorial Politics: The Cases of Vox and Podemos in Spain', Journal of Contemporary European Studies 28.3: 304-21

Vaughan, A. (2021) 'EU Plans to Plant 3 Billion Trees and Massively Expand Organic Farming', New Scientist, 20 May (accessed 12 October 2021)

Visvanathan, S. (2005) 'Knowledge, Justice and Democracy', in M. Leach, I. Scoones and B. Wynne (eds), Science and Citizens: Globalization and the Challenge of Engagement, London and New York NY: Zed Books

Weis, T. (2013) The Ecological Hoofprint: The Global Burden of Industrial Livestock, London and New York NY: Zed Books

Willett, W. et al. (2019) 'Food in the Anthropocene: The EAT-Lancet Commission on Healthy Diets from Sustainable Food Systems', The Lancet 393.10170: 447-92 
Wilson, E.O. (2016) Half-Earth: Our Planet's Fight for Life, New York NY: WW Norton \& Company

World Economic Forum (2021) The Future of Protein (accessed 12 October 2021)

Zhuang, M.; Gongbuzeren; and Li, W. (2017) 'Greenhouse Gas Emission of Pastoralism is Lower than Combined Extensive/Intensive Livestock Husbandry: A Case Study on the Qinghai-Tibet Plateau of China', Journal of Cleaner Production 147: 514-22 
This page is intentionally left blank 